Check for updates

Cite this: New J. Chem., 2021 45,13429

Received 22nd March 2021 Accepted 17th June 2021 DOI: 10.1039/d1nj01400e rsc.li/njc

\section{Synthesis, structural analysis, electrochemical and magnetic properties of tetrachloroferrate ionic liquids $\dagger$}

\author{
Anham Zafar, ${ }^{a b}$ Imtiaz-ud-Din., (D) ${ }^{b}$ Safeer Ahmed, (iD ${ }^{b}$ Dejan-Krešimir Bučar, (iD) ${ }^{a}$ \\ Muhammad Nawaz Tahir ${ }^{c}$ and Robert G. Palgrave (iD *a
}

\begin{abstract}
Eight ionic liquids have been synthesized with the tetrachloroferrate anion and varying cations with the general formula of $[R A]^{+}\left[\mathrm{FeCl}_{4}\right]^{-}\left(\mathrm{R}=-\mathrm{CH}_{3},-\mathrm{CH}_{2} \mathrm{C}_{6} \mathrm{H}_{5} ; \mathrm{A}=\right.$ pyridine, benzimidazole, trimethylamine, triphenylphosphine). They were characterized using spectroscopic techniques such as FT-IR, ESI-MS, Raman, and AAS along with single-crystal XRD to validate their structural motifs. The ionic conductivity, electrochemical and magnetic properties were determined to assess their possible uses in synthesis, separation, magnetic and transportation technologies, and high-energy capacitors. The diffusion coefficient value for these compounds was calculated to be around $7.55 \times 10^{-8} \mathrm{~cm}^{2} \mathrm{~s}^{-1}$ and the heterogeneous rate constant value is about $3.60 \times 10^{-3} \mathrm{~cm} \mathrm{~s}^{-1}$, which quantitatively complemented not only quasi reversibility but also moderately fast electron transfer processes. The effective magnetic moment values for the ionic liquids were determined to be similar to that expected from the spin-only approximation.
\end{abstract}

\section{Introduction}

Ionic liquids (ILs) are unique chemical materials that have attracted steeply increasing scientific interest over the past few years due to their diverse applications. ${ }^{1}$ The peculiar and distinctive characteristics of ILs offer enhanced proficiency for numerous processes and quality products that make a rationale to investigate their prospects further. ${ }^{2}$ They have a huge potential in future ground-breaking technologies, while some ILs have already made their approach from the laboratory to practical applications as well and are applied successfully in various electro-analytical, ${ }^{3}$ energy generation/storage, ${ }^{4}$ synthetic, ${ }^{5}$ and engineering applications. ${ }^{6}$ The first-row transition metal ions in $\mathrm{di}^{-},{ }^{7}$ tri- $^{8}$ or tetra-valent ${ }^{9}$ form exhibit interesting catalytic performances ${ }^{10,11}$ and fascinating magnetic behaviour. ${ }^{12,13}$ Metal-containing ionic liquids offer synergic effects to the materials as reports have manifested that the incorporation of iron in their anions generates significant electrochemical, ${ }^{14}$ magnetic, ${ }^{15}$ photophysical ${ }^{16}$ and catalytic properties. $^{10,17}$

In the present study, the electrochemical behaviour of tetrachloroferrate anions with various cations has been investigated.

\footnotetext{
${ }^{a}$ Department of Chemistry, University College London, 20 Gordon Street, London, WC1E 0AJ, UK. E-mail: r.palgrave@ucl.ac.uk

${ }^{b}$ Department of Chemistry, Quaid-i-Azam University, Islamabad 45320, Pakistan

${ }^{c}$ Department of Physics, University of Sargodha, Sargodha 40100, Pakistan

$\dagger$ Electronic supplementary information (ESI) available. CCDC 1519185 and 2045996 for 2 and 6. For ESI and crystallographic data in CIF or other electronic format see DOI: 10.1039/d1nj01400e
}

The sole purpose is to assess the reproducibility and sustainability of charge-transfer processes and to demonstrate the nonadsorptive nature of these compounds on the surface of the working electrode. The ionic liquids, as a class, possess high conductivities relative to conventional organic and non-aqueous solvents or electrolytes, which make them adjustable for use in various appliances. ${ }^{18}$ Some reports have manifested the active role of ILs in the development of high-energy ${ }^{19}$ and energystorage devices. $^{20}$ The presence of tetrachloroferrate (high-spin $\mathrm{d}^{5}$ iron $\left.\mathrm{III}\right)$ anions, including their combination with several cations, is considered to be the cause of various rare properties such as magnetic separation, super-exchange magnetic interactions, gas adsorption, cellulose dissolution and environmental remediation. ${ }^{21}$ The iron-incorporated ILs cause strong sensitivity to magnetic fields, which suggests the additional benefit of their ease of recycling and recoverability. ${ }^{15}$ The magnetic susceptibilities of these magnetic ionic liquids (MILs) were measured at temperatures that may enable advanced potential application prospects in the fields of catalytic reactions and separation processes in comparison with conventional ILs. ${ }^{22}$

The designability of tetrachloroferrate as an anion and appropriate structural modification have opened a new dimension to ionic liquids and their applications in various fields. Keeping these aspects in view and as a continuation of our earlier work, ${ }^{23,24}$ we report herein the synthesis, structural elucidation of iron-incorporated MILs to further explore their utility in a diverse field of studies. Their unique characteristics, such as a wide range of physico-chemical properties, high conductivities and magnetic 
susceptibility data, could be exploited in electrical as well as magnetic separation techniques in addition to synthetic chemistry.

\section{Materials and methods}

All reagents and solvents were purchased from Sigma-Aldrich Chemicals and used without further purification. The NMR spectra were taken in $\mathrm{D}_{2} \mathrm{O} / \mathrm{DMSO}$ as a solvent and recorded using a Bruker Avance III 600 spectrometer. The FTIR spectra were recorded using a Thermo Shimadzu FT-IR Spectrophotometer (750-3400 $\mathrm{cm}^{-1}$ ) with a resolution of $4 \mathrm{~cm}^{-1}$. A Renishaw inVia Raman microscope was used to record the Raman spectra. The acquisition time was $20 \mathrm{~s}$, the excitation wavelength $785 \mathrm{~nm}$ (130 $\mathrm{mW}, 10 \%)$ and the laser spot $1 \mu^{2}$. Electrospray mass spectrometry analyses were performed using the Vanquisher LC system connected to an Orbitrap Exactive Plus mass spectrometer operating in positive ionization mode with a HESI ion source. The metal concentration was determined using an atomic absorption spectrophotometer with an air- $\mathrm{C}_{2} \mathrm{H}_{2}$ flame (Shimadzu AA-670 Japan). Optimum conditions for the analysis of iron were using a hollow cathode lamp (HCL) with a current of $8 \mathrm{~mA}$, slit width 0.2 and wavelength $248.3 \mathrm{~nm}$. A conductometer (Art. Nr. 103635) was used to measure the conductance of the synthesized compounds. The magnetic susceptibility was measured using an Evans balance developed by Dennis Evans in 1973. All the voltammetric measurements were carried out using an Eco Chemie Autolab PGSTAT 302 potentiostat/galvanostat at an applied potential $( \pm 2$ $\mathrm{mV})$ and current $( \pm 0.2 \mathrm{~A})$.

\section{Synthesis}

The iron-containing ionic liquids (1-8) were synthesized using a reported methodology with slight modifications ${ }^{25}$ comprising of two steps. The first step involves the synthesis of the required cation through a quaternization reaction whereas the second step deals with an anion-exchange reaction that results in the preparation of ionic liquids as the target compounds. The synthesized products include methyl and benzyl substituentbased cations, and tetrachloroferrate as the anionic moiety.

\section{Methyl-based ionic liquids (1-4)}

The quaternization reaction was carried out to prepare the methyl-based cation by taking stoichiometric amounts of methyl iodide with the respective amine such as pyridine, benzimidazole, trimethylamine or triphenylphosphine and stirring for around 7 hours in THF. ${ }^{26,27}$ The methyl-based iodide salts $\left(\mathbf{I}_{\mathbf{1}}-\mathbf{I}_{\mathbf{4}}\right)$, thus formed, were filtered off and the filtrate was discarded as unreacted materials. The halide salt prepared must be precluded from intense light to avert decomposition. A stoichiometric amount of iron(III) chloride, dissolved in $6 \mathrm{M}$ hydrochloric acid, was mixed with methyl-based iodide salts and stirred for another 4-5 hours. ${ }^{28}$ The hydrogen iodide, thus produced, was removed by washing with ethyl acetate. The methyl-based ionic liquids (1-4) were obtained and purified by recrystallization in a mixture of solvents: dichloromethane and $n$-hexane $(1: 3)$ as enunciated in (Scheme 1).

Methylpyridinium iodide ( $\left.\mathrm{I}_{\mathbf{1}}\right) .{ }^{1} \mathrm{H}$ NMR $\left(600 \mathrm{MHz}, \mathrm{D}_{2} \mathrm{O}\right), \delta$ : $8.80\left(\mathrm{~d},{ }^{2} J_{\mathrm{HH}}=6.00 \mathrm{~Hz}, 2 \mathrm{H}\right), 8.54\left(\mathrm{t},{ }^{3} J_{\mathrm{HH}}=6.00 \mathrm{~Hz}, 1 \mathrm{H}\right), 8.05\left(\mathrm{t},{ }^{3} J_{\mathrm{HH}}=\right.$ $12.00 \mathrm{~Hz}, 2 \mathrm{H}), 4.40$ (s, 3H). ${ }^{13} \mathrm{C}$ NMR (150 MHz, $\left.\mathrm{D}_{2} \mathrm{O}\right), \delta: 48.74$, 128.55, 145.67, 145.88. ESI-MS: [methylpyridinium] ${ }^{+}$94.06.

Dimethylbenzimidazolium iodide $\left(\mathrm{I}_{2}\right) .{ }^{1} \mathrm{H}$ NMR $(600 \mathrm{MHz}$, $\left.\mathrm{D}_{2} \mathrm{O}\right), \delta: 9.19(\mathrm{~s}, 1 \mathrm{H}), 7.89(\mathrm{~m}, 2 \mathrm{H}), 7.74(\mathrm{~m}, 2 \mathrm{H}), 4.11(\mathrm{~s}, 6 \mathrm{H}) .{ }^{13} \mathrm{C}$ NMR (150 MHz, $\left.\mathrm{D}_{2} \mathrm{O}\right), \delta: 33.38,113.47,127.40,132.57,142.45$. ESI-MS: [dimethylbenzimidazolium] ${ }^{+} 147.09$.

Tetramethylammonium iodide $\left(\mathrm{I}_{3}\right) .{ }^{1} \mathrm{H}$ NMR $(600 \mathrm{MHz}$, $\left.\mathrm{D}_{2} \mathrm{O}\right), \delta: 3.20(\mathrm{~s}, 12 \mathrm{H}) .{ }^{13} \mathrm{C}$ NMR $\left(150 \mathrm{MHz}, \mathrm{D}_{2} \mathrm{O}\right), \delta: 55.85$. ESIMS: [tetramethylammonium] $]^{+} 74.09$.

Methyltriphenylphosphonium iodide ( $\left.\mathbf{I}_{4}\right) \cdot{ }^{1} \mathrm{H}$ NMR $(600 \mathrm{MHz}$, $\left.\mathrm{D}_{2} \mathrm{O}\right), \delta: 7.72(\mathrm{~m}, 15 \mathrm{H}), 2.90(\mathrm{~s}, 3 \mathrm{H}) .{ }^{13} \mathrm{C} \mathrm{NMR}\left(150 \mathrm{MHz}, \mathrm{D}_{2} \mathrm{O}\right), \delta$ : 8.84, 119.55, 130.57, 133.83, 135.52. ESI-MS: [methyltriphenylphosphonium] $]^{+}$277.11.

Methylpyridinium tetrachloroferrate(III) (1). Quantities used: methylpyridinium iodide ( $2 \mathrm{mmol}), \mathrm{HFeCl}_{4}(2 \mathrm{mmol})$; yellowish crystalline product; m.p.: $117{ }^{\circ} \mathrm{C}$; anal. calcd (\%) for $\left[\mathrm{CH}_{3}\left(\mathrm{C}_{5} \mathrm{H}_{5}\right) \mathrm{N}\right]-$ $\mathrm{FeCl}_{4}$ (292): C, 24.70; H, 2.76; N, 4.80; Fe, 19.17; found (\%): C, 24.69; H, 2.74; N, 4.77; Fe, 19.13; FT-IR $\left(\mathrm{cm}^{-1}\right): \nu \mathrm{N}-\mathrm{C}(1190), \nu \mathrm{C}=\mathrm{N}$ (1633), $\nu \mathrm{C}=\mathrm{C}$ (1487), $\nu \mathrm{HC}$ (3070).

Dimethylbenzimidazolium tetrachloroferrate(III) (2). Quantities used: dimethylbenzimidazolium (3 mmol), $\mathrm{HFeCl}_{4}(3 \mathrm{mmol})$; greenish crystalline product; m.p.: $120{ }^{\circ} \mathrm{C}$; anal. calcd (\%) for $\left[\left(\mathrm{C}_{7} \mathrm{H}_{5}\right) \mathrm{N}_{2} \mathrm{C}_{2} \mathrm{H}_{6}\right] \mathrm{FeCl}_{4}$ (345) C, 31.35; H, 3.21; N, 8.12; Fe, 16.19; found \%: C, 31.32; H, 3.19; N, 8.08; Fe, 16.21; FT-IR $\left(\mathrm{cm}^{-1}\right) \nu \mathrm{N}-\mathrm{C}$ (1135), $\nu \mathrm{C}=\mathrm{N}$ (1612), $\nu \mathrm{C}=\mathrm{C}$ (1442), $\nu \mathrm{HC}$ (3093).

Tetramethylammonium tetrachloroferrate(III) (3). Quantities used: tetramethylammonium iodide ( $4 \mathrm{mmol}), \mathrm{HFeCl}_{4}(4 \mathrm{mmol})$; brownish yellow crystalline product; m.p.: $123{ }^{\circ} \mathrm{C}$; anal. calcd (\%) for $\left[\left(\mathrm{CH}_{3}\right)_{4} \mathrm{~N}\right] \mathrm{FeCl}_{4}(272)$ : C, 17.68; H, 4.45; N, 5.15; Fe, 20.55; found \%: C, 17.66; H, 4.42; N, 5.11; Fe, 20.56; FT-IR $\left(\mathrm{cm}^{-1}\right) \nu \mathrm{N}-\mathrm{C}$ (1009), $\nu \mathrm{HC}$ (2985).

Methyltriphenylphosphonium tetrachloroferrate(II) (4). Quantities used: methyltriphenylphosphonium ( $3 \mathrm{mmol}), \mathrm{HFeCl}_{4}(3 \mathrm{mmol})$; light yellowish crystalline product; m.p.: $155{ }^{\circ} \mathrm{C}$; anal. calcd (\%) for
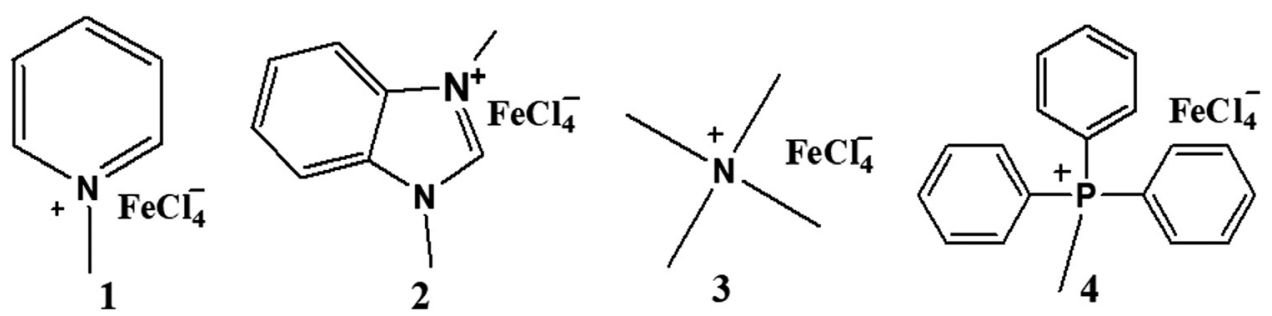

Scheme 1 Structures of methyl-based ionic liquids. 

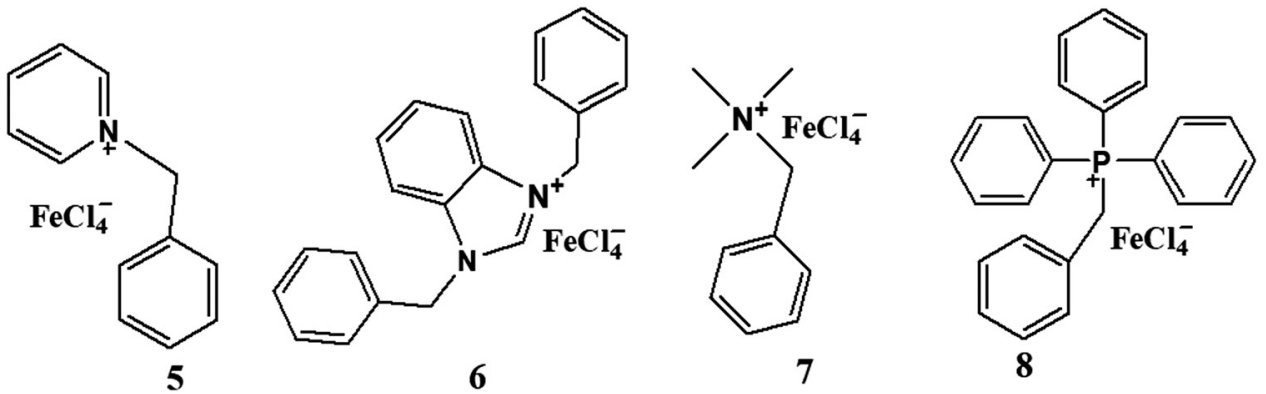

Scheme 2 Structures of benzyl-based ionic liquids.

$\left[\mathrm{CH}_{3}\left(\mathrm{C}_{6} \mathrm{H}_{5}\right)_{3} \mathrm{P}\right] \mathrm{FeCl}_{4}$ (475): C, 48.05; H, 3.82; $\mathrm{Fe}, 11.77$; found \%: C, 48.02; H, 3.80; Fe, 11.74; FT-IR $\left(\mathrm{cm}^{-1}\right) \nu \mathrm{P}-\mathrm{C}(1486), \nu \mathrm{C}=\mathrm{C}$ (1633), $\nu \mathrm{HC}$ (3068).

\section{Benzyl-based ionic liquids $\left.{ }_{5-8}\right)$}

The quaternization reaction was carried out to synthesize the cations of interest. Benzyl chloride and the respective amine or $\mathrm{PPh}_{3}$ in stoichiometric amounts were mixed and refluxed in THF for 48 hours. ${ }^{29}$ The benzyl-based chloride salts $\left(\mathbf{I}_{5}-\mathbf{I}_{\mathbf{8}}\right)$ were formed and filtered off to remove the unreacted impurities, then dried in a vacuum but not heated above $80{ }^{\circ} \mathrm{C}$ to avoid the reverse reaction. Then stoichiometric amounts of these synthesized benzyl-based chloride species and iron salts $\left(\mathrm{FeCl}_{3} \cdot 6 \mathrm{H}_{2} \mathrm{O}\right)$ were stirred for another 4-5 hours in methanol ${ }^{30,31}$ to get the target compounds (5-8), which were subsequently purified by washing with diethyl ether (Scheme 2).

Benzylpyridinium chloride ( $\left.\mathrm{I}_{5}\right) .{ }^{1} \mathrm{H}$ NMR $\left(600 \mathrm{MHz}, \mathrm{D}_{2} \mathrm{O}\right), \delta$ : $8.91\left(\mathrm{~d},{ }^{2} J_{\mathrm{HH}}=6 \mathrm{~Hz}, 2 \mathrm{H}\right), 8.56\left(\mathrm{t},{ }^{3} J_{\mathrm{HH}}=6 \mathrm{~Hz}, 1 \mathrm{H}\right), 8.07\left(\mathrm{t},{ }^{3} J_{\mathrm{HH}}=\right.$ $6.6 \mathrm{~Hz}, 2 \mathrm{H}), 7.51(\mathrm{~m}, 5 \mathrm{H}) 5.83(\mathrm{~s}, 2 \mathrm{H}) .{ }^{13} \mathrm{C} \mathrm{NMR}\left(150 \mathrm{MHz}, \mathrm{D}_{2} \mathrm{O}\right)$, $\delta: 65.19,128.95,129.70,130.55,133.30,144.93,146.58$. ESI-MS: [benzylpyridinium] ${ }^{+} 170.10$.

Dibenzylbenzimidazolium chloride $\left(\mathbf{I}_{\mathbf{6}}\right) .{ }^{1} \mathrm{H}$ NMR $(600 \mathrm{MHz}$, $\left.\mathrm{D}_{2} \mathrm{O}\right), \delta: 9.39(\mathrm{~s}, 1 \mathrm{H}), 7.86(\mathrm{~m}, 2 \mathrm{H}), 7.61(\mathrm{~m}, 2 \mathrm{H}), 7.46(\mathrm{~m}, 10 \mathrm{H})$, $5.71(\mathrm{~s}, 4 \mathrm{H}) .{ }^{13} \mathrm{C}$ NMR $\left(150 \mathrm{MHz}, \mathrm{D}_{2} \mathrm{O}\right), \delta: 51.36,113.68,114.26$, 127.72, 128.82, 133.54, 139.51, 141.70. ESI-MS: [dibenzylbenzimidazolium] $]^{+} 299.15$.

Benzyltrimethylammonium chloride $\left(\mathrm{I}_{7}\right) .{ }^{1} \mathrm{H}$ NMR $(600 \mathrm{MHz}$, $\left.\mathrm{D}_{2} \mathrm{O}\right), \delta: 7.55(\mathrm{~m}, 5 \mathrm{H}), 4.48(\mathrm{~s}, 2 \mathrm{H}), 3.08(\mathrm{~s}, 9 \mathrm{H}) .{ }^{13} \mathrm{C} \mathrm{NMR}$ $\left(150 \mathrm{MHz}, \mathrm{D}_{2} \mathrm{O}\right), \delta: 52.90,70.13,128.05,129.71,131.36,133.34$. ESI-MS: [benzyltrimethylammonium] ${ }^{+} 150.12$.

Benzyltriphenylphosphonium chloride $\left(\mathrm{I}_{8}\right) .{ }^{1} \mathrm{H}$ NMR $(600 \mathrm{MHz}$, DMSO), $\delta: 7.90$ (m, 3H), $7.74(\mathrm{~m}, 12 \mathrm{H}), 7.22(\mathrm{~m}, 3 \mathrm{H}), 6.97(\mathrm{~m}, 2 \mathrm{H})$, 5.17 (s, 2H). ${ }^{13} \mathrm{C}$ NMR (150 MHz, DMSO), $\delta: 29.01,117.17,118.31$, 127.36, 128.75, 130.84, 134.08, 135.15. ESI-MS: [benzyltriphenylphosphonium] $]^{+} 353.14$.

Benzylpyridinium tetrachloroferrate(III) (5). Quantities used: benzylpyridinium chloride ( $2 \mathrm{mmol}$ ), hydrated iron(III) chloride (2 mmol), clear yellowish crystalline product; m.p.: $113{ }^{\circ} \mathrm{C}$; anal. calcd (\%) for $\left[\left(\mathrm{C}_{5} \mathrm{H}_{5}\right) \mathrm{NCH}_{2} \mathrm{C}_{6} \mathrm{H}_{5}\right] \mathrm{FeCl}_{4}(368): \mathrm{C}, 39.18 ; \mathrm{H}, 3.29 ; \mathrm{N}$, 3.81; Fe, 15.18; found \%: C, 39.15; H, 3.27; N, 3.79; Fe, 15.19; FT-IR $\left(\mathrm{cm}^{-1}\right) \nu \mathrm{N}-\mathrm{C}(1157), \nu \mathrm{C}=\mathrm{N}(1628), \nu \mathrm{C}=\mathrm{C}$ (1486), $\nu \mathrm{HC}$ (3059).

Dibenzylbenzimidazolium tetrachloroferrate(III) (6). Quantities used: dibenzylbenzimidazolium chloride $(3 \mathrm{mmol})$, hydrated
iron(III) chloride (3 mmol); light yellowish crystalline product; m.p.: $119{ }^{\circ} \mathrm{C}$; anal. calcd (\%) for $\left[\left(\mathrm{C}_{7} \mathrm{H}_{5}\right) \mathrm{N}_{2}\left(\mathrm{CH}_{2} \mathrm{C}_{6} \mathrm{H}_{5}\right)_{2}\right] \mathrm{FeCl}_{4}$ (497): C, 50.69; H, 3.84; N, 5.65; Fe, 11.30; found \%: C, 50.70; H, 3.82; N, 5.63; Fe, 11.32; FT-IR $\left(\mathrm{cm}^{-1}\right) \nu \mathrm{N}-\mathrm{C}(1108), \nu \mathrm{C}=\mathrm{N}$ (1618), $\nu \mathrm{C}=\mathrm{C}$ (1434), $\nu \mathrm{HC}$ (3052).

Benzyltrimethylammonium tetrachloroferrate(III) (7). Quantities used: benzyltrimethylammonium chloride $(2 \mathrm{mmol})$, hydrated iron(III) chloride ( $2 \mathrm{mmol}$ ); yellowish crystalline product; m.p.: $111{ }^{\circ} \mathrm{C}$; anal. calcd (\%) for $\left[\left(\mathrm{CH}_{3}\right)_{3} \mathrm{NCH}_{2} \mathrm{C}_{6} \mathrm{H}_{5}\right] \mathrm{FeCl}_{4}$ (348) \%: C, 34.52; H, 4.64; N, 4.03; Fe, 16.05; found \%: C, 34.49; $\mathrm{H}, 4.61 ; \mathrm{N}, 4.00 ; \mathrm{Fe}, 16.03$; FT-IR $\left(\mathrm{cm}^{-1}\right) \nu \mathrm{N}-\mathrm{C}$ (1003), $\nu \mathrm{HC}$ (2994), $\nu \mathrm{C}=\mathrm{C}$ (1478).

Benzyltriphenylphosphonium tetrachloroferrate(III) (8). Quantities used: benzyltriphenylphosphonium chloride (3 mmol), hydrated iron(III) chloride ( $3 \mathrm{mmol}$ ); light yellowish crystalline product; m.p.: $112{ }^{\circ} \mathrm{C}$; anal. calcd (\%) for $\left[\left(\mathrm{C}_{6} \mathrm{H}_{5}\right)_{3} \mathrm{PCH}_{2} \mathrm{C}_{6} \mathrm{H}_{5}\right] \mathrm{FeCl}_{4}$ (551): C, 54.49; $\mathrm{H}, 4.02$; Fe, 10.13; found \%: C, 54.45; H, 4.05; Fe, 10.15; FT-IR $\left(\mathrm{cm}^{-1}\right)$ $\nu \mathrm{PC}$ (1437), $\nu \mathrm{C}=\mathrm{C}$ (1641), $\nu \mathrm{HC}$ (2911).

\section{X-Ray crystallography}

Single crystals of 2 and $\mathbf{6}$ were obtained via slow solvent evaporation from dichloromethane and methanol solutions, respectively.

A suitable crystal for 2 was selected and mounted on a Bruker kappa APEXII CCD single-crystal X-ray diffractometer using the micro focus $\operatorname{MoK}_{\alpha}$ X-ray beam $(\lambda=0.71073 \AA)$. The crystal was kept at $296 \mathrm{~K}$ during the data collection. The data were corrected using a Lorentz polarization absorption correction. The crystal structure was solved and refined using the ShelXS-97 and ShelXL programmes. ${ }^{32}$ Single X-ray diffraction data for compound 6 was collected using a dual-source Agilent SuperNova single-crystal X-ray diffractometer using a micro-focus $\mathrm{Cu}$ X-ray beam $(\lambda=$ $1.54184 \AA$, generated at $50 \mathrm{kV}$ and $0.8 \mathrm{~mA}$ ) and a $135 \mathrm{~mm}$ Atlas CCD detector. The sample temperature was controlled using an Oxford Instruments Cryojet5. The data were acquired, processed and corrected using the CrysAlisPro program. ${ }^{33}$ Structure solution and refinement were accomplished using the Olex 2 program suite. ${ }^{34}$ The structure was solved using SHELXT, ${ }^{35}$ while structure refinement was accomplished using SHELXL. ${ }^{36}$ All non-hydrogen atoms of 2 and 6 were refined anisotropically, while hydrogen atoms associated with the carbon atoms were refined isotropically in geometrically constrained positions $\left[U_{\text {iso }}(\mathrm{H})=1.2 U_{\text {eq }}(\mathrm{C})\right]$. The crystallographic and refinement parameters for $\mathbf{2}$ and $\mathbf{6}$ are shown in Table 2. 


\section{Voltammetric analysis}

All the voltammetric measurements were carried out using an Eco Chemie Autolab PGSTAT 302 potentiostat/galvanostat, Utrecht, The Netherlands, having GPES 4.9. A conventional three-electrode system was employed using a Platinum disc as the working electrode with an area of $0.017 \mathrm{~cm}^{2}$, Pt wire the counter electrode and $\mathrm{Ag}$ wire the reference electrode calibrated against the standard $\mathrm{Fc}^{+} / \mathrm{Fc}$ couple (potential $=0.493 \mathrm{~V}$ vs. $\mathrm{Ag} / \mathrm{AgCl}$ and $0.601 \mathrm{~V}$ vs. $\mathrm{Ag}$ wire). A control (blank scan) was run using deionized water and $0.1 \mathrm{M} \mathrm{KCl}$ as the supporting electrolyte, to ensure the electroinactivity of the medium, prior to analyzing the ionic liquids. The response of $1 \mathrm{mM}$ of the ionic liquid was checked in both the absence and the presence of the supporting electrolyte. The cyclic voltammetric data were calculated at different scan rates (from 0.02 to $1.2 \mathrm{~V} \mathrm{~s}^{-1}$ ) at $28{ }^{\circ} \mathrm{C} \pm 0.5$.

\section{Ionic conductance}

A conductometer (Art. Nr. 103635) was used to measure the ionic conductance of 1-8 for $1 \mathrm{mM}, 0.5 \mathrm{mM}$ and $0.4 \mathrm{mM}$ solutions in deionized water.

\section{Magnetic susceptibility}

An Evans balance was used to measure the magnetic susceptibility of the synthesized iron-containing ILs. This instrument works with the help of two permanent magnets equipped back-to-back and endorsed by the suspension strip. An optical transducer detects a deflection when the sample tube is inserted between the two magnets. One of these two magnets has a coil attached with it, through which a counteracted current is passed. The sample exerts some force on the magnet, which is proportional to the applied current to the coil to counteract the force and therefore allows for a reading to be taken.

For paramagnetic materials, the gram magnetic susceptibility $\chi_{\mathrm{g}}$ must be a positive number and it is calculated from the following equation $\left[\chi_{\mathrm{g}}=l \times C_{\mathrm{Bal}}\left(R-R_{0}\right) /\left(m \times 10^{9}\right)\right]$ where $l=$ length of the sample in the tube $(\mathrm{cm}), C_{\mathrm{Bal}}=$ balance calibration constant, $R=$ the measurement taken with the sample, $R_{0}=$ the measurement taken without the sample, and $m=$ sample mass in grams.

From the gram magnetic susceptibility, the molar magnetic susceptibility $\chi_{\mathrm{m}}$ and $\mu_{\text {eff }}$ are calculated using the following relationships $\left[\chi_{\mathrm{m}}=\chi_{\mathrm{g}} \cdot\right.$ molecular weight; $\left.\mu_{\mathrm{eff}}=2.828\left(\chi_{\mathrm{m}} \cdot T\right)^{1 / 2}\right]$. However, a correction must be made as the magnetic field will be weakly repelled from the pair of electrons in compounds. ${ }^{37}$

\section{Results and discussion}

Eight iron-incorporated ILs with varying cations substituted with methyl and benzyl groups, respectively, have been synthesized, and the details are enunciated in scheme 3.

The synthesized compounds are stable at room temperature. They were characterized using FTIR, Raman, AAS and singlecrystal X-ray analyses along with mass spectrometry. One of the significant IR absorption bands for the methyl-containing ILs (1-4) is the stretching frequency of $\nu_{(\mathrm{C}-\mathrm{H})}$, which appears around $3000 \mathrm{~cm}^{-1}$ that ensured the occurrence of methylation for all the precursors.

The absence of the stretching frequency for $\nu_{(\mathrm{N}-\mathrm{H})}$ at $3300 \mathrm{~cm}^{-1}$, present in benzimidazole, in benzimidazolium salts 2 and 6 indicates that methylation has occurred, that is, the $\mathrm{H}$ of the $\mathrm{NH}$ functionality has been replaced by a methyl group. The stretching frequency for $\nu_{(\mathrm{N}-\mathrm{C})}$ appeared in the range of $1000-1300 \mathrm{~cm}^{-1}$ for methyl-containing ionic liquids 1-3, and the stretching frequency for $\nu_{(\mathrm{P}-\mathrm{C})}$ in the case of 4 occurred at around $1438 \mathrm{~cm}^{-1}$. The IR absorption band for $\nu_{(\mathrm{C}-\mathrm{H})}$ appeared at around $3000 \mathrm{~cm}^{-1}$ in the benzyl-containing halide salts 5-8. The appearance of the absorption band in the range of $1000-1160 \mathrm{~cm}^{-1}$ indicated that the methylene of benzyl chloride is attached to the nitrogen of

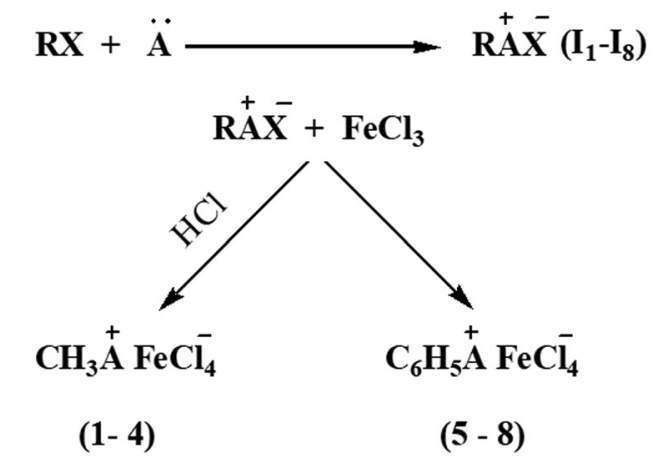

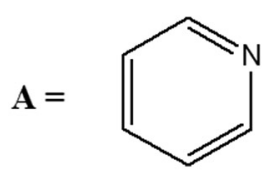

$(1,5)$<smiles>c1ccc2[nH]cnc2c1</smiles>

$(2,6)$<smiles>CN(C)C</smiles>

$(3,7)$<smiles>c1ccc(P(c2ccccc2)c2ccccc2)cc1</smiles>

$(4,8)$

Scheme 3 Synthetic pathway for 1-8. 
Table 1 Atomic absorption spectroscopic data for 1-8

\begin{tabular}{lll}
\hline MILs & Calculated (\%) & Observed (\%) \\
\hline $\mathbf{1}$ & 19.17 & 19.13 \\
$\mathbf{2}$ & 16.19 & 16.21 \\
$\mathbf{3}$ & 20.55 & 20.56 \\
$\mathbf{4}$ & 11.77 & 11.74 \\
$\mathbf{5}$ & 15.18 & 15.19 \\
$\mathbf{6}$ & 11.30 & 11.32 \\
7 & 16.05 & 16.03 \\
$\mathbf{8}$ & 10.13 & 10.15
\end{tabular}

the precursors 5-7. The appearance of the IR absorption band around $1437 \mathrm{~cm}^{-1}$ indicates the attachment of methylene (of benzyl chloride) to the phosphine moiety as for $\mathbf{8}$.

Atomic absorption spectroscopic quantification data indicated that the calculated and observed values of iron $\left(\mathrm{Fe}^{3+}\right)$ are in accordance with each other, as depicted in Table 1 . The calculated and observed values of iron deviate within the range of $\pm 0.05 \%$.

The electrospray analysis using mass spectrometry for 1-8 was operated in positive ionization mode with a HESI ion source, which confirms the presence of the corresponding cations. ESI-MS for 1-8 are shown as follows:

1: $\left[\mathrm{C}_{6} \mathrm{H}_{8} \mathrm{~N}\right]\left[\mathrm{FeCl}_{4}\right] . \mathrm{m} / z\left(\mathrm{ESI}^{\left.-\mathrm{MS}^{+}\right):} 94.06(100 \%)\left[\mathrm{C}_{6} \mathrm{H}_{8} \mathrm{~N}\right]^{+}\right.$.

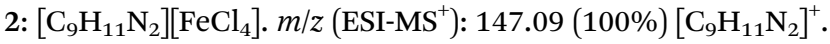

3: $\left[\mathrm{C}_{4} \mathrm{H}_{12} \mathrm{~N}\right]\left[\mathrm{FeCl}_{4}\right] \cdot m / z\left(\mathrm{ESI}^{\left.-\mathrm{MS}^{+}\right):} 74.09(100 \%)\left[\mathrm{C}_{4} \mathrm{H}_{12} \mathrm{~N}\right]^{+}\right.$.

4: $\left[\mathrm{C}_{19} \mathrm{H}_{18} \mathrm{P}\right]\left[\mathrm{FeCl}_{4}\right] . m / z\left(\mathrm{ESI}^{\left.-\mathrm{MS}^{+}\right)} 277.11(100 \%)\left[\mathrm{C}_{19} \mathrm{H}_{18} \mathrm{P}\right]^{+}\right.$.

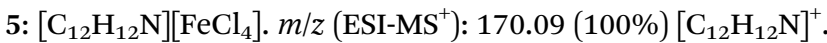

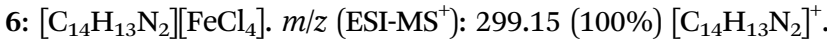

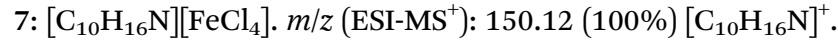

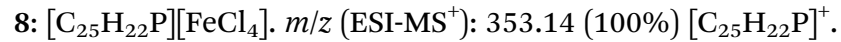
The Raman spectra of all the synthesized ILs are similar in the region $200-500 \mathrm{~cm}^{-1}$, indicating their identical anionic structure. In the literature, the band at $332 \mathrm{~cm}^{-1}$ is assigned to the totally symmetric $\mathrm{Fe}-\mathrm{Cl}$ stretching vibration of $\mathrm{FeCl}_{4} \cdot{ }^{38,39}$ Hence, this validated that all the synthesized ionic liquids have the same $\left[\mathrm{FeCl}_{4}\right]$ anion. The Raman spectra for 1-8 are shown in Fig. S22 (ESI $\dagger$ ).

Single-crystal X-ray analyses were carried out to authenticate the crystal structures of 2 and 6 . Both salts crystallise in the monoclinic space group $P 2_{1} / c$ with one benzimidazolium cation and one tetrachloroferrate(III) anion in the asymmetric unit. The structural data of the MILs containing benzimidazole as the cation with tetrachloroferrate(III) have been studied less compared with other types of cations in spite of their extensive applications in green catalysis ${ }^{40}$ and as magnetic materials. ${ }^{41}$ So far, a very limited number of articles have appeared in the literature, showing X-ray single-crystal analysis of dialkylbenzimidazolium-based ILs with iron(III) chloride. ${ }^{42-44}$ The crystal structures of $\mathbf{2}$ and $\mathbf{6}$ are shown in Fig. 1 and their crystallographic data and selected bond lengths and angles are listed in Tables 2 and 3 , respectively.

The cations are composed of the benzimidazolium core with methyl and benzyl chains, and the corresponding dialkylbenzimidazolium moiety, in both the structures, is not discernibly changed after reaction of the iron(III) salt, which is in accordance with previously published reports. ${ }^{45}$ The anion $\left[\mathrm{FeCl}_{4}\right]^{-}$

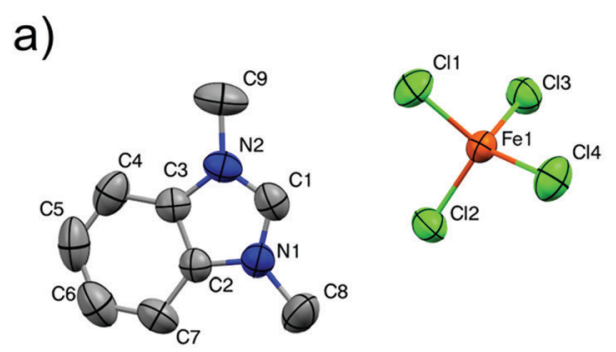

b)
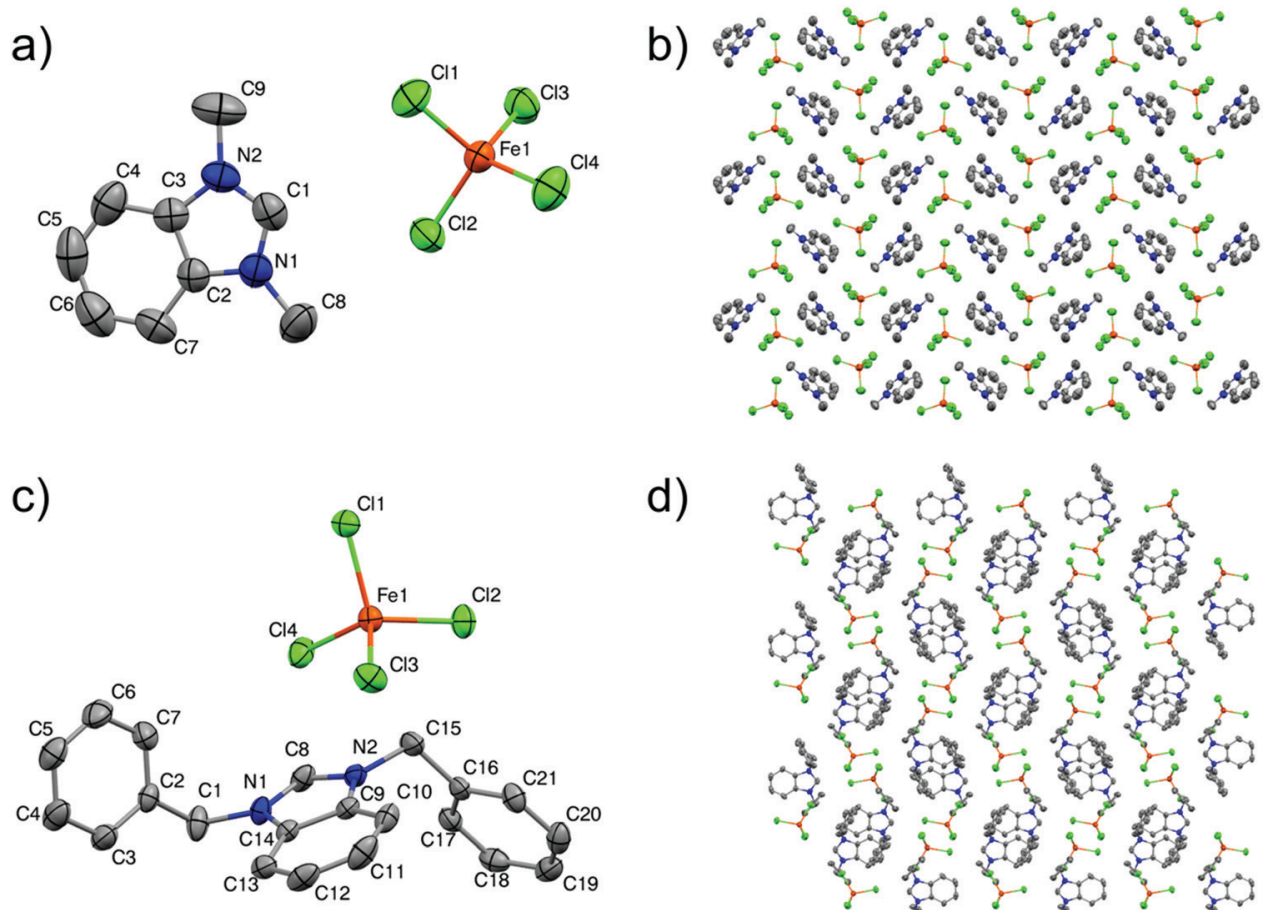

d)

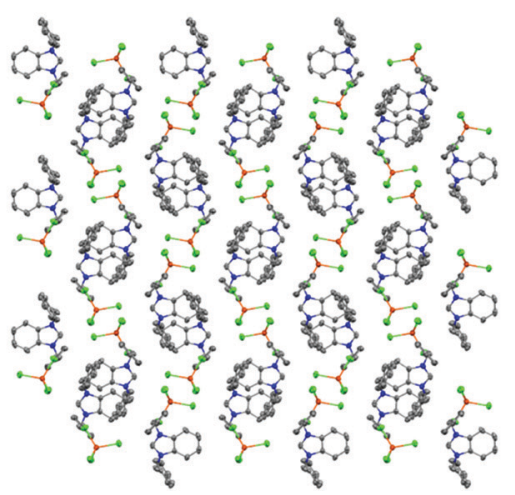

Fig. 1 X-Ray crystal structure of $\mathbf{2}$ and $\mathbf{6}$ : (a) perspective view of the asymmetric unit of $\mathbf{2}$, (b) crystal packing of $\mathbf{2}$ viewed along the crystallographic axis a, (c) perspective view of the asymmetric unit of $\mathbf{6}$, (d) crystal packing of $\mathbf{6}$ viewed along the crystallographic axis a. The thermal ellipsoids are drawn at the $50 \%$ probability level. All hydrogen atoms are omitted to enhance the clarity of the diagrams. 
Table 2 Crystallographic and refinement parameters of 2 and 6

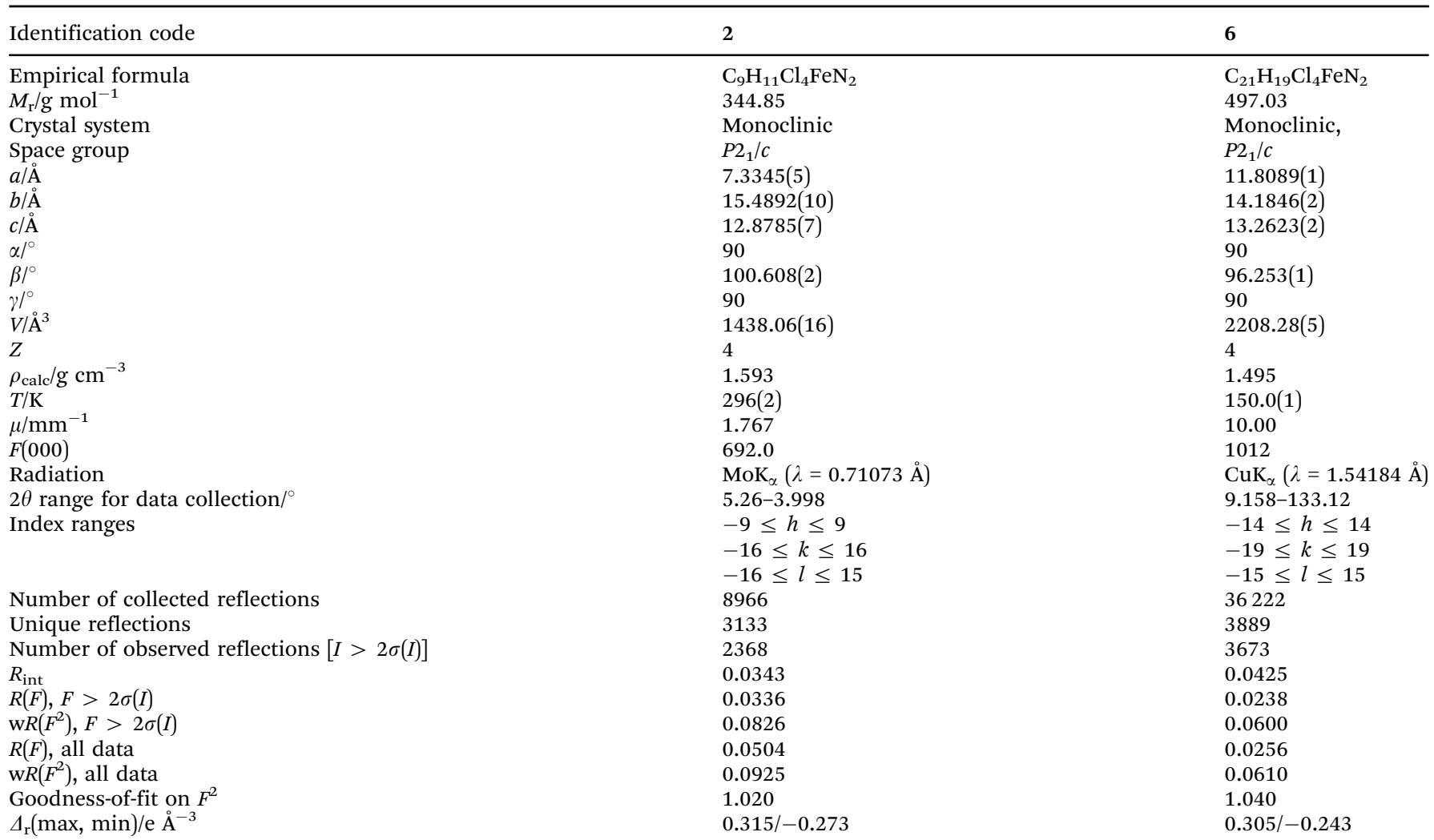

Table 3 Selected bond lengths $(\AA)$ and bonds angles $\left(^{\circ}\right)$ for 2 and 6

\begin{tabular}{lll}
\hline & 2 & 6 \\
\hline Bond lengths/A & & \\
$\mathrm{Fe}(1)-\mathrm{Cl}(4)$ & $2.1853(8)$ & $2.1948(5)$ \\
$\mathrm{Fe}(1)-\mathrm{Cl}(3)$ & $2.1912(8)$ & $2.1937(5)$ \\
$\mathrm{Fe}(1)-\mathrm{Cl}(2)$ & $2.1938(8)$ & $2.1957(5)$ \\
$\mathrm{Fe}(1)-\mathrm{Cl}(1)$ & $2.1967(7)$ & \\
& & \\
$\mathrm{Bond}$ angles/ & & $110.05(2)$ \\
$\mathrm{Cl}(4)-\mathrm{Fe}(1)-\mathrm{Cl}(3)$ & $110.00(3)$ & $110.66(2)$ \\
$\mathrm{Cl}(4)-\mathrm{Fe}(1)-\mathrm{Cl}(2)$ & $110.39(3)$ & $108.31(2)$ \\
$\mathrm{Cl}(3)-\mathrm{Fe}(1)-\mathrm{Cl}(2)$ & $109.12(3)$ & $107.16(2)$ \\
$\mathrm{Cl}(4)-\mathrm{Fe}(1)-\mathrm{Cl}(1)$ & $111.13(3)$ & $109.49(2)$ \\
$\mathrm{Cl}(3)-\mathrm{Fe}(1)-\mathrm{Cl}(1)$ & $110.09(3)$ & \\
$\mathrm{Cl}(2)-\mathrm{Fe}(1)-\mathrm{Cl}(1)$ & $106.02(3)$ &
\end{tabular}

has a distorted tetrahedral geometry by coordinating with four chlorides. The bond lengths of $\mathrm{Fe}-\mathrm{Cl}$ are found in the range of

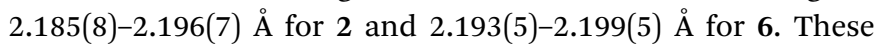
values are in good agreement with previous studies. ${ }^{46}$ The mean values of the $\mathrm{Cl}-\mathrm{Fe}-\mathrm{Cl}$ angles for 2 and 6 are 109.39(3) and $109.47(2)^{\circ}$, respectively, which are the values for $\left[\mathrm{FeCl}_{4}\right]^{-}$ found in the literature. ${ }^{47}$

The ions interact with each other in both the structures through $\mathrm{C}-\mathrm{H} \cdots \mathrm{Cl}, \pi(\mathrm{C}-\mathrm{C}) \cdots \mathrm{Cl}$ and $\pi(\mathrm{C}-\mathrm{N}) \cdots \mathrm{Cl}$ contacts. The cations and anions are arranged in parallel layers and the interactions generated a 3-D packing network in both the structures, as illustrated in Fig. 1. Hydrogen bonding has not been observed in $\mathbf{6}$, which is analogous to previous reports having bulky imidazoliumbased cations, ${ }^{48,49}$ while in the case of 2 the cations and anions
Table 4 Hydrogen bonds for 2

\begin{tabular}{lllllll}
\hline $\mathrm{D}$ & $\mathrm{H}$ & $\mathrm{A}$ & $d(\mathrm{D}-\mathrm{H}) / \AA$ & $d(\mathrm{H}-\mathrm{A}) / \AA$ & $d(\mathrm{D}-\mathrm{A}) / \AA$ & $\mathrm{D}-\mathrm{H}-\mathrm{A})^{\circ}$ \\
\hline $\mathrm{C}(4)$ & $\mathrm{H}(4)$ & $\mathrm{Cl}(3)$ & 0.93 & 2.85 & $3.696(3)$ & 152.6 \\
$\mathrm{C}(8)$ & $\mathrm{H}(8) \mathrm{B}$ & $\mathrm{Cl}(1)$ & 0.96 & 2.84 & $3.760(4)$ & 161.1 \\
$\mathrm{C}(8)$ & $\mathrm{H}(8) \mathrm{C}$ & $\mathrm{Cl}(2)$ & 0.96 & 2.92 & $3.608(4)$ & 129.8 \\
$\mathrm{C}(9)$ & $\mathrm{H}(9) \mathrm{B}$ & $\mathrm{Cl}(2)$ & 0.96 & 2.93 & $3.569(3)$ & 125.4
\end{tabular}

have the $\mathrm{C}-\mathrm{H} \cdots \mathrm{Cl}$ interaction and (four) $\mathrm{H}$-bonds are formed between the acidic hydrogen at the C4-, C8- and C9-position of benzimidazole with the $\left[\mathrm{FeCl}_{4}\right]^{-}$anion at distances between 2.84 and $2.92 \AA$, and the data are presented in Table 4. However, these are very weak interactions and are not categorized as typical hydrogen bonds. Thus, one can safely assume that the cations are not static and these $\mathrm{H}$-bonds become weakened at room temperature.

Furthermore, compared with the previous structural reports on tetrachloroferrate(II)-containing ILs, the anion $\left[\mathrm{FeCl}_{4}\right]^{2-}$ has a slightly flattened tetrahedral structure compared with $\left[\mathrm{FeCl}_{4}\right]^{-}$ and the average bond length is 2.292(2) $\AA$, which is $0.11 \AA$ more than $\left[\mathrm{FeCl}_{4}\right]^{-}$due to the additional electron involved. ${ }^{50}$ The mean value for $\mathrm{Cl}-\mathrm{Fe}-\mathrm{Cl}$ bond angles is $110.18(9)^{\circ}$ ranging from a high of $113.63(11)^{\circ}$ to a low of $107.96(7)^{\circ} .^{51}$

\section{Solubility of MILs}

The solubility of all MILs in different solvents is listed in Table 5. Due to the basic dipole forces between the polar organic solvent and the ILs, all the synthesized ILs have very 
Table 5 Solubility data ${ }^{a}$ for the MILs

\begin{tabular}{|c|c|c|c|c|c|c|c|c|c|c|c|c|}
\hline MILs & $\mathrm{H}_{2} \mathrm{O}$ & $\mathrm{MeOH}$ & EtOH & $\mathrm{ACN}$ & DMSO & DCM & $\mathrm{CCl}_{4}$ & THF & DMF & EtOAc & $\mathrm{Et}_{2} \mathrm{O}$ & $n$-Hex \\
\hline 1 & ++ & ++ & ++ & ++ & ++ & ++ & \pm & -- & -- & -- & -- & -- \\
\hline 2 & ++ & ++ & ++ & ++ & ++ & ++ & \pm & -- & -- & -- & -- & -- \\
\hline 3 & ++ & ++ & ++ & ++ & ++ & ++ & \pm & -- & -- & -- & -- & -- \\
\hline 4 & ++ & ++ & ++ & ++ & ++ & ++ & \pm & -- & -- & -- & -- & -- \\
\hline 5 & ++ & ++ & ++ & ++ & ++ & ++ & \pm & -- & -- & -- & -- & -- \\
\hline 6 & ++ & ++ & ++ & ++ & ++ & ++ & \pm & -- & -- & -- & -- & -- \\
\hline 7 & ++ & ++ & ++ & ++ & ++ & ++ & \pm & -- & -- & -- & -- & -- \\
\hline 8 & ++ & ++ & ++ & ++ & ++ & ++ & \pm & -- & -- & -- & -- & -- \\
\hline
\end{tabular}

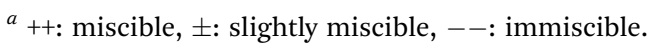

good solubility in methanol, ethanol, acetonitrile and DMSO. They are insoluble in non-polar solvents like $n$-hexane, diethyl ether and benzene. The solubility pattern of these ILs is the same as their corresponding iodide and chloride salts $\left(\mathbf{I}_{\mathbf{1}}-\mathbf{I}_{\mathbf{8}}\right)$. However, interestingly these salts are completely insoluble in chloroform and toluene, and on incorporating the iron moiety, they became partially soluble and imparted a yellow color to them.

\section{Cyclic voltammetry (CV) analysis}

The electrochemical behaviour of the MILs was determined comprehensively in both positive and negative potential regions using the cyclic voltammetry technique (Fig. 2). All the ILs were found to be electro-active in the negative potential region of 0 to $-1.2 \mathrm{~V}$ whereas $\mathbf{1 - 4}$ were found to be electroactive in the positive potential region of 0 to $1 \mathrm{~V}$ while the ILs 5-8 were apparently inactive in the positive potential region.

To observe the effect of the supporting electrolyte (KCl), the cyclic voltammograms of the ILs were recorded in both the presence and absence of the supporting electrolyte. The two redox peaks in the positive potential region were determined for 2 and 3. The cyclic voltammograms for the ILs were recorded both in the presence and absence of the supporting electrolyte $(\mathrm{KCl})$, to observe its effect.

The representative cyclic voltammograms for $\mathbf{1}$ under different conditions are shown in Fig. 2. It is apparent that recording the signal from zero towards a positive potential gave a highly reversible voltammogram without any pre- or post-peak humps. Moreover, there is a negligible difference in the two voltammograms obtained either with or without the supporting electrolyte, indicating that the ILs can suppress the migration effect and consequently reduce the unwanted capacitive current and increase the charge-transfer current. It may be construed from these findings that these materials may be used as supporting electrolytes in various electroanalytical applications depending on their inactivity in the potential range of interest.

The quasi-reversible electrochemical signature observed in the negative potential region (around $-0.6 \mathrm{~V} v s$. $\mathrm{Ag}$ wire) is ascribed to the typical reduction of pyridinium cations. ${ }^{52}$ The quasi-reversibility on the Pt electrode is the conversion of pyridinium cations to pyridine and the production of surface hydrogen gas in an aqueous medium and the adsorbed hydrogen gas is oxidized to nascent hydrogen which protonates the pyridine back to pyridinium in the reverse scan and can be used for $\mathrm{CO}_{2}$ reduction. ${ }^{53}$ On the other hand, the reversible electrooxidation, as discussed earlier, in the positive potential region is a less reported phenomenon. Compound 1 showed single reversible electrooxidation, while 2 and 3 showed two reversible electron-transport (ET) signatures whereas only an irreversible cathodic peak at $0.236 \mathrm{~V}$ was observed for 4 . The rest of compounds 5-8 did not reflect clear redox waves but a hump was observed in each case between 0.4 and $0.5 \mathrm{~V}$.

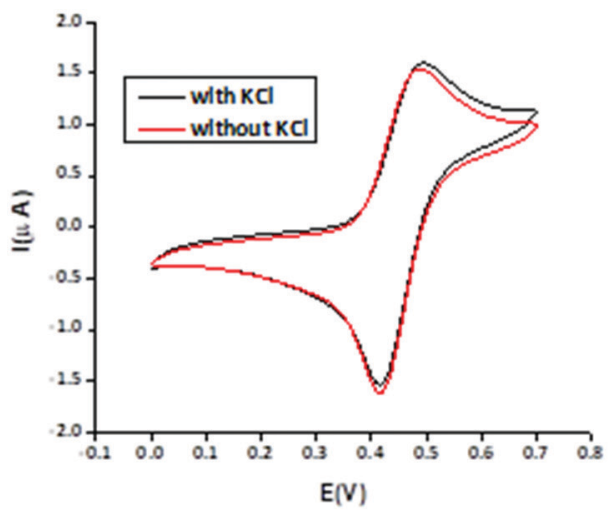

a)

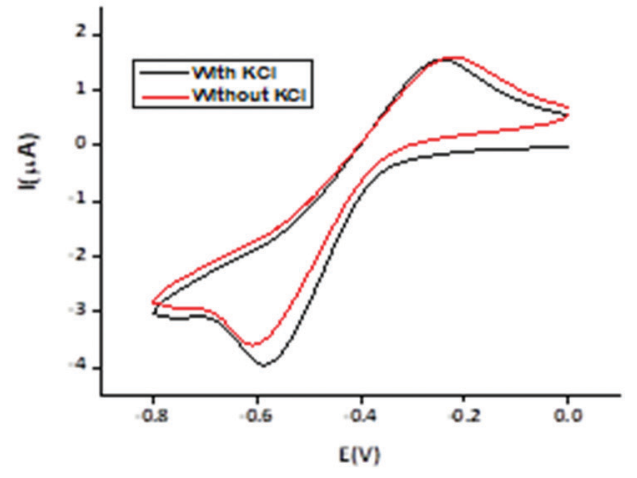

b)

Fig. 2 Cyclic voltammograms of a $1 \mathrm{mM}$ solution of 1 with $\mathrm{KCl}$, on Pt as the working electrode vs. Ag wire at $28^{\circ} \mathrm{C}$ and with a scan rate of $0.05 \mathrm{~V} \mathrm{~s}{ }^{-1}$ at (a) positive potential and at (b) negative potential. 
The apparently reversible electro-oxidation around $E_{1 / 2} \approx$ $0.5 \mathrm{~V}$ was attributed to the $\mathrm{Fe}^{3+} / \mathrm{Fe}^{2+}$ redox process, and the slight variation in peak positions is due to the presence of the reorganization energy of the complexes. This is quite analogous to the results attained for the reported molten salts of iron. ${ }^{54}$ The submergence of this redox peak from 5 to $\mathbf{8}$ could be argued to be due to the electron-donating effect of the benzyl group. This is also supported for $\mathbf{4}$, which has bulky phenyl groups (owing to their electron-donating nature), and as a result, the cathodic peak potential is at a less positive value. The second peaks for $\mathbf{2}$ and $\mathbf{3}$ are possibly the electrooxidation of the whole complex. The results of cyclic voltammetry scans are quite interesting for these compounds but still require further investigations for their possible applications in various domains of electrochemistry.

\section{Stability of MILs}

Cyclic voltammograms for the solutions of 1-8 with a concentration of $1 \mathrm{mM}$ were recorded by taking successive scans (1-10) at a constant scan rate of $0.05 \mathrm{~V} \mathrm{~s}^{-1}$ without using $\mathrm{KCl}$. The motive was to assess the reproducibility and sustainability of the charge-transfer processes in the given time scale. There is a negligible decrease in either the cathodic or anodic current for all the compounds, as exhibited in Fig. 3. This clearly demonstrates the non-adsorptive nature of the compounds on the surface of the Pt working electrode.

The essential electrochemical parameters for 1-8 are given in Tables 6 and 7. It can be inferred from the data that they exhibited their first (or the only redox wave) half wave redox potential $\left(E_{1 / 2}\right)$ around $0.5 \mathrm{~V}$ in the positive region and $-0.4 \mathrm{~V}$ in the negative region. The second redox wave was determined around $E_{1 / 2}$ of $0.8 \mathrm{~V}$ for ( 2 and 3 ). The first redox process in the positive potential region was found to be reversible as evinced from the peak width and current ratio values while the second redox process was quasi-reversible. Similarly, the redox process in the negative potential region was also found to be quasireversible for these synthesized compounds.

\section{Effect of scan rate and heterogeneous kinetics}

The CV response was studied by varying the scan rate from 0.025 to $1.200 \mathrm{~V} \mathrm{~s}^{-1}$ (Fig. 4). The changes in the voltammetric signature on the variation of the scan rate indicated the dependence of the peak potential values on the scan rate, thus confirming the quasi-reversibility of the process and that the increase in peak current was according to the Randles-Sevcik equation $^{55}\left[i_{\mathrm{p}}=\left(2.99 \times 10^{5}\right) n\left(\alpha n_{\mathrm{a}}\right)^{1 / 2} A C D^{1 / 2} v^{1 / 2}\right]$, where $v=$ scan rate $\left(\mathrm{V} \mathrm{s}^{-1}\right), C=$ concentration of electro-active species ( $\left.\mathrm{mol} \mathrm{cm} \mathrm{cm}^{-3}\right), n=$ number of electrons, $n_{a}=$ number of electrons exchanged in the rate determining step, $A=$ area of electrode $\left(\mathrm{cm}^{2}\right), \alpha=$ transfer coefficient, and $D_{\mathrm{o}}=$ diffusion coefficient $\left(\mathrm{cm}^{2} \mathrm{~s}^{-1}\right)$, which was used to calculate the diffusion coefficient values and eventually the heterogeneous rate constants by employing the Nicholson method of peak separation $\left[k^{\circ}=\right.$ $\psi\left[\pi D_{\mathrm{o}} n F v / R T\right]^{1 / 2}$, where $\psi$ is a dimensionless parameter linked to peak separation, $F$ is the Faraday constant and $R$ and $T$ have their usual significance. The linear relationship was shown in corresponding plots of the square root of the potential $v^{1 / 2} v s$. the peak current $i_{\mathrm{p}}$ (Fig. 5).

The calculated diffusion coefficient value, $7.55 \times 10^{-8} \mathrm{~cm}^{2} \mathrm{~s}^{-1}$, and the linearity of the ' $i_{\mathrm{p}} v s . v^{1 / 2}$, plots established the diffusioncontrolled nature of the electrode reaction. ${ }^{56}$ The heterogeneous rate constant value $3.60 \times 10^{-3} \mathrm{~cm} \mathrm{~s}^{-1}$ quantitatively approved the quasireversible process and the moderately fast electron-transfer process.

\section{Ionic conductivity}

The molar conductance values for 1-8 at different concentrations are presented in Table 8 . The ionic liquids are comprised entirely of ions, therefore, they have higher values of ionic conductance. ${ }^{57}$ The ionic liquids, thus, possess high conductivities in comparison with conventional organic and nonaqueous solvents $\left(\sim 10 \mathrm{mS} \mathrm{cm}^{-1}\right)$, which make them adaptable to be used as the electrolyte in various appliances. ${ }^{58}$ It is now established that the properties of the ionic liquid are highly influenced by the presence of even a very small amount of impurities such as halide ions, particularly chloride ions. ${ }^{59}$

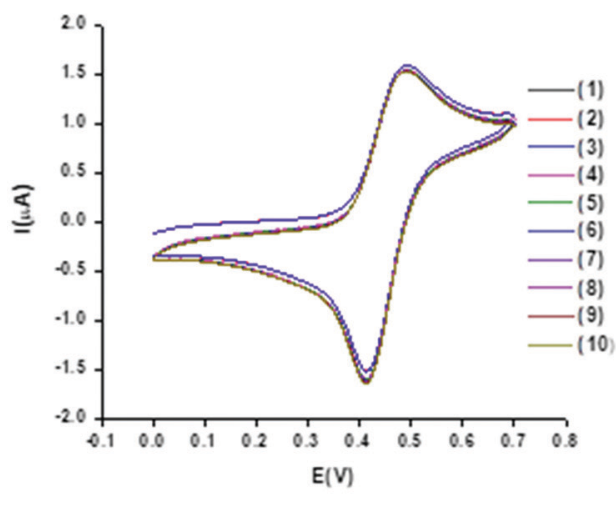

a)

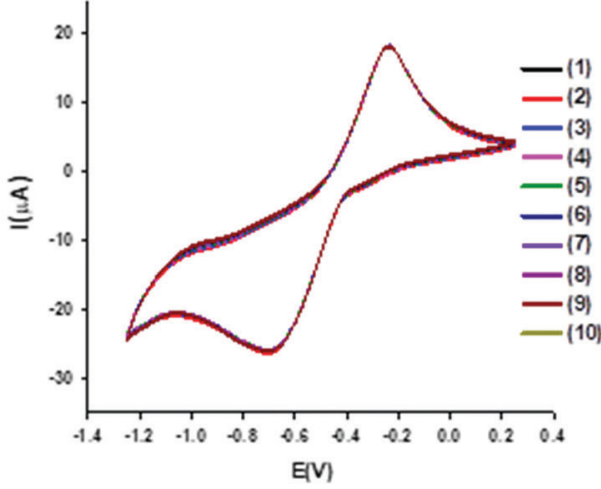

b)

Fig. 3 Cyclic voltammograms of a $1 \mathrm{mM}$ solution of 1 in deionized water with $1-10$ successive scans at $50 \mathrm{mV} \mathrm{s}^{-1}$ using a Pt electrode vs. Ag wire in (a) positive, and (b) negative potential regions. 
Table 6 Electrochemical parameters of $1 \mathrm{mM}$ ILs at scan rate of $50 \mathrm{~V} \mathrm{~s}^{-1}$ at $28^{\circ} \mathrm{C}$ in the positive potential region

\begin{tabular}{|c|c|c|c|c|c|c|c|}
\hline MILs & $\begin{array}{l}{ }^{\mathrm{a}} E_{\mathrm{p}} \\
\text { (V) }\end{array}$ & $\begin{array}{l}{ }^{\mathrm{c}} E_{\mathrm{p}} \\
(\mathrm{V})\end{array}$ & $\begin{array}{l}E_{1 / 2} \\
(\mathrm{~V})\end{array}$ & $\begin{array}{l}\Delta E_{\mathrm{p}} \\
(\mathrm{V})\end{array}$ & $\begin{array}{l}\left|{ }^{\mathrm{a}} E_{\mathrm{p}}-{ }^{\mathrm{a}} E_{\mathrm{p} / 2}\right| \\
(\mathrm{V})\end{array}$ & $\begin{array}{l}\left|{ }^{\mathrm{c}} E_{\mathrm{p}}-{ }^{\mathrm{c}} E_{\mathrm{p} / 2}\right| \\
\text { (V) }\end{array}$ & ${ }^{\mathrm{a}} i_{\mathrm{p}} /{ }^{\mathrm{c}} i_{\mathrm{p}} \mid$ \\
\hline 1 & 0.520 & 0.457 & 0.489 & 0.063 & 0.057 & -0.048 & 1.20 \\
\hline 2 (i) & 0.520 & 0.469 & 0.494 & 0.050 & 0.030 & -0.045 & 0.6 \\
\hline (ii) & 0.899 & 0.789 & 0.844 & 0.109 & 0.018 & -0.054 & 0.3 \\
\hline 3 (i) & 0.534 & 0.464 & 0.499 & 0.070 & 0.026 & -0.043 & 0.60 \\
\hline (ii) & 0.778 & 0.725 & 0.751 & 0.053 & 0.037 & -0.035 & 1.05 \\
\hline 4 & - & 0.236 & - & - & - & -0.146 & - \\
\hline 5 & - & - & - & - & - & - & - \\
\hline 6 & - & - & - & - & - & - & - \\
\hline 7 & - & - & - & - & - & - & - \\
\hline 8 & - & - & - & - & - & - & - \\
\hline
\end{tabular}

Table 7 Electrochemical parameters of $1 \mathrm{mM}$ ILs at scan rate of $50 \mathrm{~V} \mathrm{~s}^{-1}$ at $28^{\circ} \mathrm{C}$ in the negative potential region

\begin{tabular}{|c|c|c|c|c|c|c|c|}
\hline MILs & ${ }^{\mathrm{a}} E_{\mathrm{p}}(\mathrm{V})$ & ${ }^{\mathrm{c}} E_{\mathrm{p}}(\mathrm{V})$ & $E_{1 / 2}(\mathrm{~V})$ & $\begin{array}{l}\Delta E_{\mathrm{p}} \\
(\mathrm{V})\end{array}$ & $\begin{array}{l}\left|{ }^{\mathrm{a}} E_{\mathrm{p}}-{ }^{\mathrm{a}} E_{\mathrm{p} / 2}\right| \\
\text { (V) }\end{array}$ & $\begin{array}{l}\left|{ }^{\mathrm{c}} E_{\mathrm{p}}-{ }^{\mathrm{c}} E_{\mathrm{p} / 2}\right| \\
\text { (V) }\end{array}$ & $\left|{ }^{\mathrm{a}} i_{\mathrm{p}} /{ }^{\mathrm{c}} i_{\mathrm{p}}\right|$ \\
\hline 1 & -0.241 & -0.564 & -0.402 & 0.323 & 0.140 & -0.097 & 1.44 \\
\hline 2 & -0.251 & -0.583 & -0.417 & 0.337 & 0.120 & -0.044 & 1.45 \\
\hline 3 & -0.374 & -0.459 & -0.416 & 0.832 & 0.048 & -0.046 & 1.04 \\
\hline 4 & -0.278 & -0.549 & -0.413 & 0.271 & 0.131 & -0.090 & 1.26 \\
\hline 5 & -0.300 & -0.551 & -0.425 & 0.251 & 0.106 & -0.080 & 1.32 \\
\hline 6 & -0.229 & -0.710 & -0.469 & 0.481 & 0.136 & -0.085 & 1.60 \\
\hline 7 & -0.207 & -0.651 & -0.429 & 0.444 & 0.136 & -0.143 & 1.00 \\
\hline 8 & -0.127 & -0.986 & -0.556 & 0.859 & 0.172 & -0.055 & 3.1 \\
\hline
\end{tabular}

The conductivity of ionic liquids, in general, is weakly interrelated with the type and size of ions, whereas the anionic size and type are not linked with the conductance. As illustrated from the molar conductance values, the ionic liquids with a higher cationic size show higher conductance because there is more delocalization of charge and more charge-charge separation; consequently, they conduct electricity more efficiently. This effect is more dominant over the steric hindrance, which decreases the mobility of ions owing to the larger size. ${ }^{60}$ The higher conductivity values of these compounds made them promising candidates for electrolytes and high-energy capacitors. ${ }^{61}$
The molar conductivity values of the IL solutions increase with increasing concentration due to the increase in the effective concentration of ions as well as the ionic strength.

\section{Magnetic studies}

The ionic liquids exhibit paramagnetic behavior over a wide range of temperatures. Values of the product of molar susceptibility and temperature $\left(\chi_{\mathrm{M}} T\right)$ for 1-8 were determined in the range of 3.49-4.50 (emu mol $\left.{ }^{-1} \mathrm{~K} \mathrm{Oe}^{-1}\right)$ whereas the reported value is 4.37 (emu $\mathrm{mol}^{-1} \mathrm{~K}$ ) for the $\mathrm{Fe}^{3+}$ system. At temperatures higher than $20 \mathrm{~K}$, the magnetic susceptibility data follow the Curie-Weiss law with Weiss temperatures and the effective paramagnetic moment value was determined to be $\left[\mu_{\text {eff }}\right]=$ $5.66 \mu_{\mathrm{B}}$ for an $\mathrm{Fe}^{3+}$ system, which is consistent with the literature value reported for a high-spin $\mathrm{d}^{5}$ system (Table 9). The data revealed that the calculated $\mu_{\text {eff }}$ values for the synthesized MILs, owing to the $\mathrm{FeCl}_{4}{ }^{-}$moiety, are in good agreement with the reported values. ${ }^{62}$ The gram and molar susceptibilities of the synthesized MILs are also listed in Table S5 (ESI $\dagger$ ).

Various counter cations have also been examined with the transition-metal based ILs, generally with a high-spin $\mathrm{d}^{5}$ system as for the tetrachloroferrate(III) anion. ${ }^{59}$ The synthesized MILs described a strong response to the externally applied magnetic fields due to their high single-ion magnetic moments. ${ }^{63}$ The MILs are not only influenced by the applied magnetic field but are also able to separate and transport the diamagnetic materials depending upon their magnetic susceptibility and density parameters. ${ }^{64}$ The data suggest that the cationic moiety did not interfere with the unpaired electrons of the metal but may enhance its magnetic character at a wide range of temperatures. The characteristic physical and magnetic properties of the reported compounds have been critically reviewed and a comparative account has been illustrated in Table 9.

\section{Conclusion}

Eight iron-incorporated ionic liquids have been synthesized and their chemical and structural aspects were characterized

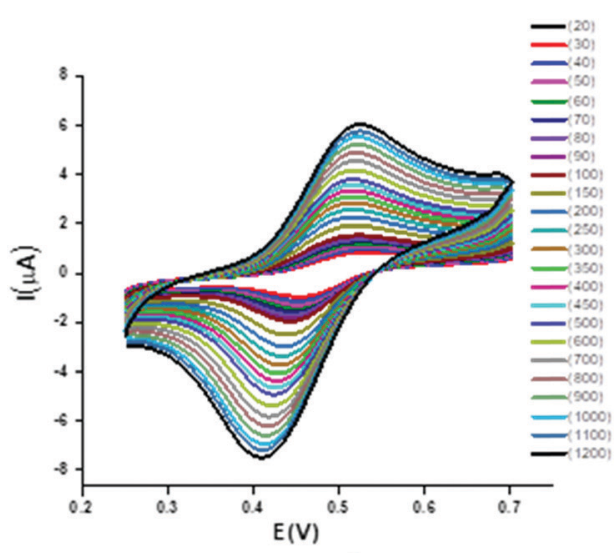

a)

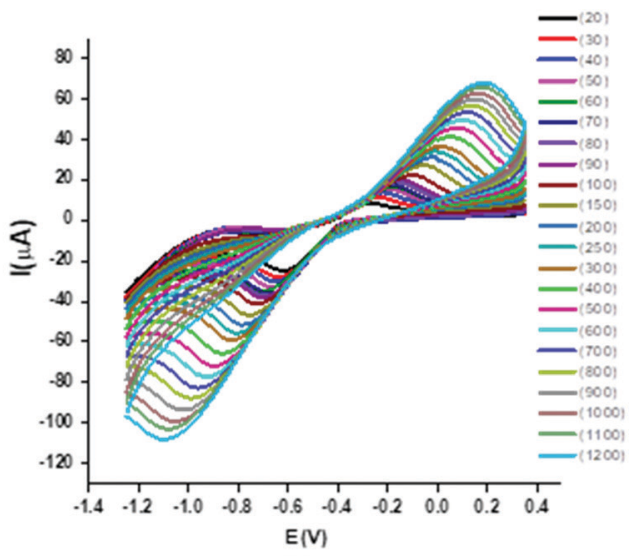

b)

Fig. 4 Cyclic voltammograms of a $1 \mathrm{mM}$ solution of 1 in deionized water at $20-1200 \mathrm{mV} \mathrm{s}{ }^{-1}$ using a Pt electrode vs. Ag wire in (a) positive and (b) negative potential regions. 


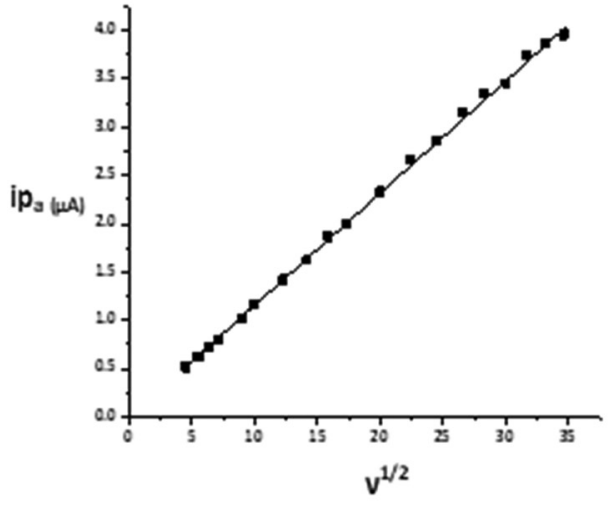

a)

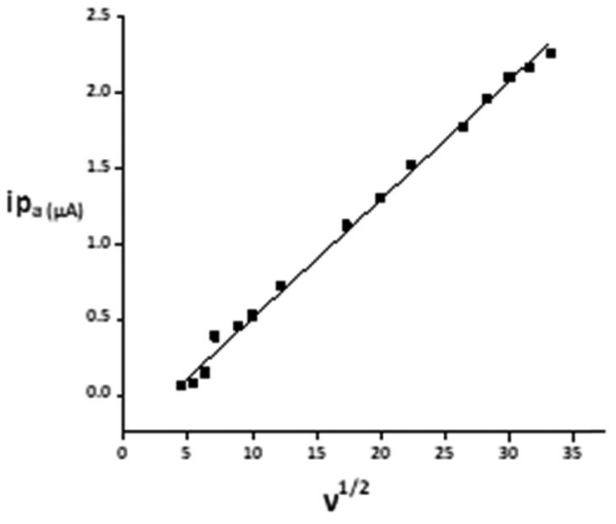

b)

Fig. 5 Plot of $i_{p} v s . v^{1 / 2}$ for a $1 \mathrm{mM}$ solution for 1 in deionized water in (a) positive and (b) negative potential regions.

Table 8 Molar conductance values for $\mathbf{1 - 8}$ at different concentrations at $298 \mathrm{~K}$

\begin{tabular}{llll}
\hline MILs & $1 \mathrm{mM}\left(\mathrm{mS} \mathrm{cm}^{-1}\right)$ & $0.5 \mathrm{mM}\left(\mathrm{mS} \mathrm{cm}^{-1}\right)$ & $0.4 \mathrm{mM}\left(\mathrm{mS} \mathrm{cm}^{-1}\right)$ \\
\hline $\mathbf{1}$ & 10.99 & 5.28 & 4.21 \\
$\mathbf{2}$ & 9.22 & 4.54 & 3.63 \\
$\mathbf{3}$ & 7.68 & 3.55 & 2.82 \\
$\mathbf{4}$ & 12.02 & 6.23 & 4.99 \\
$\mathbf{5}$ & 5.16 & 2.55 & 2.08 \\
$\mathbf{6}$ & 8.36 & 4.12 & 3.27 \\
7 & 10.44 & 5.07 & 4.17 \\
$\mathbf{8}$ & 10.09 & 4.94 & 3.99
\end{tabular}

using spectroscopic and single-crystal XRD techniques. Cyclic voltammetry data validated the electro-active and non-adsorptive nature of the synthesized ILs. From the diffusion coefficient and rate constant values, it may be inferred that the redox reactions of ILs are diffusion-controlled and moderately fast electron-transfer processes. They are promising candidates for electrolytic and highenergy capacitor appliances due to their higher values of conductivity. The synthesized MILs exhibited significant magnetic properties and their effective magnetic moment values demonstrated that they may find applications in material sciences as well. The literature suggests that iron-containing ILs show magnetically

Table 9 Comparison of the characteristic properties and magnetic susceptibilities of $\mathrm{FeCl}_{4}$-based synthesized MILs with the literature at room temperature

\begin{tabular}{|c|c|c|c|c|c|c|c|}
\hline Cation & $\begin{array}{l}\text { M.p. } \\
\left({ }^{\circ} \mathrm{C}\right)\end{array}$ & $\begin{array}{l}d \\
\left(\mathrm{~g} \mathrm{~cm}^{-3}\right)\end{array}$ & $\begin{array}{l}\eta \\
(\mathrm{mPa})\end{array}$ & $\begin{array}{l}\text { Yield } \\
(\%)\end{array}$ & $\begin{array}{l}\chi_{\mathrm{M}} T \\
\left(\mathrm{emu} \mathrm{mol}{ }^{-1} \mathrm{~K}\right)\end{array}$ & $\begin{array}{l}\mu_{\text {eff }} \\
\left(\mu_{\mathrm{B}}\right)\end{array}$ & Ref. \\
\hline 1-Butyl-3-methylimidazolium & -8.29 & 1.38 & 340 & - & 4.11 & 5.73 & Hayashi et al., $2004^{65}$ \\
\hline 1-Decyl-3-methylimidazolium & - & - & - & - & 4.01 & 5.66 & Del Sesto et al., $2008^{63}$ \\
\hline Tricaprylylmethylammonium & - & - & - & - & 3.2 & 5.02 & D. Kogelnig et al., $2010^{68}$ \\
\hline Tetrabutylammonium & 130 & - & - & 88 & 4.27 & 5.84 & Krieger et al., $2010^{69}$ \\
\hline Methylbutylpyrrolidinium & 191 & - & - & 76 & 4.47 & 5.98 & Krieger et al., $2010^{69}$ \\
\hline Dibutylbenzimidazolium & 70 & - & - & 76 & 3.9 & 5.56 & Wang, Ke Fei, et al., $2011^{41}$ \\
\hline Butylpyridinium & 38.4 & - & - & - & 4.31 & 5.85 & W. Zhu et al., $2013^{71}$ \\
\hline N-Decylpyridinium & 10 & 1.63 & 719.5 & 95 & - & - & Zhuravle et al., $2014^{72}$ \\
\hline 1,3-Dimethylimidazolium & 285 & - & - & 91 & 4.25 & 5.83 & García-Saiz et al., $2014^{73}$ \\
\hline 1,3-Dibenzylbenzimidazolium & 175 & - & - & 87 & - & - & LI et al., $2017^{42}$ \\
\hline 1-Hexyl-3-methylimidazolium & - & 1.30 & 450 & - & - & 5.80 & X. Li et al., $2017^{74}$ \\
\hline 1-Octyl-3-methylimidazolium & - & 1.24 & 770 & - & - & 5.85 & X. Li et al., $2017^{74}$ \\
\hline 1,3-Dimethylbenzimidazolium (2) & 120 & - & - & 96 & 3.49 & 5.27 & This work \\
\hline Tetramethylammonium (3) & 123 & - & - & 93 & 3.72 & 5.44 & This work \\
\hline Methyltriphenylphosphonium (4) & 155 & - & - & 94 & 4.50 & 5.98 & This work \\
\hline Benzylpyridinium (5) & 113 & - & - & 93 & 3.82 & 5.51 & This work \\
\hline 1,3-Dibenzylbenzimidazolium (6) & 119 & - & - & 95 & 3.95 & 5.60 & This work \\
\hline Benzyltrimethylammonium (7) & 111 & - & - & 92 & 4.23 & 5.84 & This work \\
\hline Benzyltriphenylphosphonium (8) & 112 & - & - & 93 & 4.31 & 5.86 & This work \\
\hline
\end{tabular}

M.p.: melting point, $d$ : density, $\eta$ : viscosity, $\chi_{\mathrm{M}} T$ : magnetic susceptibility, $\mu_{\text {eff: }}$ effective paramagnetic moment, - : not reported. 
active properties and are attracted by an external magnetic field that may be used for the magnetic manipulation and transportation of $\mathrm{N}_{2}$ bubbles in catalytic and polymerization reactions as well as for a photo-controllable paramagnetic supramolecular system. Moreover, the intermixing of ionic liquids and the electrode materials may become beneficial for the development of environmentally friendly sophisticated storage devices.

\section{Abbreviations}

$\begin{array}{ll}\text { ILs } & \text { Ionic liquids } \\ \text { MILs } & \text { Magnetic ionic liquids } \\ \text { AAS } & \text { Atomic absorption spectroscopy } \\ \text { mM } & \text { Millimolar } \\ \text { THF } & \text { Tetrahydrofuran } \\ \text { DCM } & \text { dichloromethane } \\ \text { DMF } & \text { Dimethylformamide } \\ \text { ACN } & \text { Acetonitrile }\end{array}$

\section{Conflicts of interest}

The authors declare no competing interests.

\section{Acknowledgements}

AZ acknowledges the Commonwealth Scholarship and the Franz Sondheimer Bursary received from University College London.

\section{References}

1 A. J. Greer and J. Jacquemin, Molecules, 2020, 25, 5207.

2 C. Kolbeck, M. Killian, F. Maier, N. Paape, P. Wasserscheid and H. P. Steinrück, Langmuir, 2008, 24, 9500-9507.

3 J. L. Anderson and D. W. Armstrong, Anal. Chem., 2006, 78, 2893-2902.

4 D. R. MacFarlane, M. Forsyth, P. C. Howlett, M. Kar, S. Passerini, J. M. Pringle, H. Ohno, M. Watanabe, F. Yan, W. Zheng, S. Zhang and J. Zhang, Nat. Rev. Mater., 2016, 1, 1-15.

5 Suresh and J. S. Sandhu, Green Chem. Lett. Rev., 2011, 4, 289-310.

6 A. Berthod, M. J. Ruiz-Ángel and S. Carda-Broch, J. Chromatogr. A, 2008, 1184, 6-18.

7 I. Castro, M. L. Calatayud, C. Yuste, M. Castellano, R. RuizGarcía, J. Cano, J. Faus, M. Verdaguer and F. Lloret, Polyhedron, 2019, 169, 66-77.

8 E. Pardo, F. Lloret, R. Carrasco, M. C. Muñoz, T. TemporalSánchez and R. Ruiz-García, Inorg. Chim. Acta, 2004, 357, 2713-2720.

9 R. Ruiz, A. Aukauloo, Y. Journaux, I. Fernández, J. R. Pedro, A. L. Roselló, B. Cervera, I. Castro and M. C. Muñoz, Chem. Commun., 1998, 989-990.

10 S. E. Fortea-Pérez, F. R. Moubtassim, M. L. E. I. Armentano, D. D. Munno, G. Julve and M. Stiriba, Inorg. Chem. Front., 2018, 5, 2148-2156.
11 F. R. Fortea-Pérez, D. Armentano, M. Julve, G. D. Munno and S. E. Stiriba, J. Coord. Chem., 2014, 67, 4003-4015.

12 M. Castellano, R. Ruiz-García, J. Cano, J. Ferrando-Soria, E. Pardo, F. R. Fortea-Pérez, S. E. Stiriba, M. Julve and F. Lloret, Acc. Chem. Res., 2015, 48, 510-520.

13 M. Castellano, R. Ruiz-García, J. Cano, J. Ferrando-Soria, E. Pardo, F. R. Fortea-Pérez, S. E. Stiriba, W. P. Barros, H. O. Stumpf, L. Cañadillas-Delgado, J. Pasán, C. Ruiz-Pérez, G. de Munno, D. Armentano, Y. Journaux, F. Lloret and M. Julve, Coord. Chem. Rev., 2015, 303, 110-138.

14 D. M. Cabral, P. C. Howlett and D. R. MacFarlane, Electrochim. Acta, 2016, 220, 347-353.

15 A. Joseph, G. Zyła, V. I. Thomas, P. R. Nair, A. S. Padmanabhan and S. Mathew, J. Mol. Liq., 2016, 218, 319-331.

16 R. Decadt, K. Van Hecke, D. Depla, K. Leus, D. Weinberger, I. Van Driessche, P. Van Der Voort and R. Van Deun, Inorg. Chem., 2012, 51, 11623-11634.

17 J. Wang, S. Zeng, F. Huo, D. Shang, H. He, L. Bai, X. Zhang and J. Li, J. Cleaner Prod., 2019, 206, 661-669.

18 Y. Yoshida, A. Otsuka, G. Saito, S. Natsume, E. Nishibori, M. Takata, M. Sakata, M. Takahashi and T. Yoko, Bull. Chem. Soc. Jpn., 2005, 78, 1921-1928.

19 N. Böckenfeld, S. S. Jeong, M. Winter, S. Passerini and A. Balducci, J. Power Sources, 2013, 221, 14-20.

20 A. Brandt, S. Pohlmann, A. Varzi, A. Balducci and S. Passerini, MRS Bull., 2013, 38, 554-559.

21 B. Tobias, O. Breunig, M. Valldor, K. Merz, V. Vasylyeva, A. Mudring and D. Bochum, Cryst. Growth Des., 2011, 11, 2564-2571.

22 K. Bica and P. Gaertner, Eur. J. Org. Chem., 2008, 3453-3456.

23 M. Mehmood, Imtiaz-ud-Din., A. Raheel, I. Haq and M. Nawaz, Heliyon, 2020, 6, e05156.

24 T. Fatima, A. Akbar, M. Sabieh, M. T. Nawaz and Imtiaz-udDin., J. Mol. Struct., 2019, 1184, 462-467.

25 R. Engel, J. L. I. Rizzo, C. Rivera, M. Ramirez, M. L. Huang, D. Montenegro, C. Copodiferro, V. Behaj, M. Thomas, B. Klaritch-vrana and J. F. Engel, Chem. Phys. Lipids, 2009, 158, 61-69.

26 P. Bonhte, A. P. Dias, N. Papageorgiou, K. Kalyanasundaram and M. Grätzel, Inorg. Chem., 1996, 35, 1168-1178.

27 J. Sun, M. Forsyth and D. R. Macfarlane, J. Phys. Chem. B, 1998, 8858-8864.

28 J. S. Wilkes and M. J. Zaworotko, J. Chem. Soc., Chem. Commun., 1992, 965-967.

29 A. G. Böwing and A. Jess, Green Chem., 2005, 7, 230-235.

30 M. S. Sitze, E. R. Schreiter, E. V. Patterson, R. G. Freeman, D. Science and E. Normal, Inorg. Chem., 2001, 2298-2304.

31 A. Elaiwi, P. B. Hitchcock, K. R. Seddon, N. Srinivasan, Y. M. Tan, T. Welton and J. A. Zora, J. Chem. Soc., Dalton Trans., 1995, 3467-3472.

32 G. M. Sheldrick, Acta Crystallogr., Sect. A: Found. Crystallogr., 2008, 64, 112-122.

33 R. Naeem, M. Ali Ehsan, R. Yahya, M. Sohail, H. Khaledi and M. Mazhar, Dalton Trans., 2016, 45, 14928-14939.

34 O. V. Dolomanov, L. J. Bourhis, R. J. Gildea, J. A. K. Howard and H. Puschmann, J. Appl. Crystallogr., 2009, 42, 339-341. 
35 G. M. Sheldrick, Acta Crystallogr., Sect. A: Found. Crystallogr., 2014, 3-8.

36 G. M. Sheldrick, Acta Crystallogr., Sect. C: Struct. Chem., 2014, 3-8. 37 G. A. Bain and J. F. Berry, J. Chem. Educ., 2008, 85, 532-536.

38 W. Jiang, W. Zhu, Y. Chang, Y. Chao, S. Yin, H. Liu, F. Zhu and H. Li, Chem. Eng. J., 2014, 250, 48-54.

39 X. Pei, Y. H. Yan, L. Yan, P. Yang, J. Wang, R. Xu and M. B. Chan-Park, Carbon, 2010, 48, 2501-2505.

40 H. Olivier-Bourbigou, L. Magna and D. Morvan, Appl. Catal., A, 2010, 373, 1-56.

41 K. F. Wang, L. Zhang, R. R. Zhuang and F. F. Jian, Transition Met. Chem., 2011, 36, 785-791.

42 Z. Li, B. Lu, H. Sun, Q. Shen and Y. Zhang, Appl. Organomet. Chem., 2017, 31, 1-7.

43 C. L. Xia, C. F. Xie, Y. F. Wu, H. M. Sun, Q. Shen and Y. Zhang, Org. Biomol. Chem., 2013, 11, 8135-8144.

44 C. H. Yan, L. L. Wang, H. H. Gao, H. M. Sun and Q. Shen, Chin. Sci. Bull., 2012, 57, 1953-1958.

45 E. Despagnet-Ayoub, K. Miqueu, J. M. Sotiropoulos, L. M. Henling, M. W. Day, J. A. Labinger and J. E. Bercaw, Chem. Sci., 2013, 4, 2117-2121.

46 T. Bäcker, O. Breunig, M. Valldor, K. Merz, V. Vasylyeva and A. V. Mudring, Cryst. Growth Des., 2011, 11, 2564-2571.

47 T. Głowiak, E. Ďurčanská, I. Ondrejkovičová and G. Ondrejovič, Acta Crystallogr., Sect. C: Cryst. Struct. Commun., 1986, 42(10), 1331-1333.

48 A. Thirumurugan and C. N. R. Rao, Cryst. Growth Des., 2008, 8, 1640-1644.

49 H. N. Deng, Y. L. Xing, C. L. Xia, H. M. sun and Q. Shen, J. Chem. Soc., Dalton Trans., 1972, 1772.

$50 \mathrm{~J}$. W. Lauher and J. A. Ibers, Inorg. Chem., 1975, 14, 348-352.

51 C. Zhong, T. Sasaki, A. Jimbo-Kobayeshi, E. Fujiwara, A. Kobayashi, M. Tada and Y. Iwasawa, Bull. Chem. Soc. Jpn., 2007, 80, 2365-2374.

52 E. Martínez-González, H. G. Laguna, M. Sánchez-Castellanos, S. S. Rozenel, V. M. Ugalde-Saldivar and C. Amador-Bedolla, ACS Appl. Energy Mater., 2020, 3, 8833-8841.

53 E. Lebègue, J. Agullo and D. Bélanger, ChemSusChem, 2018, 11, 219-228.

54 Y. Castrillejo, A. M. Martínez, M. Vega, E. Barrado and G. Picard, J. Electroanal. Chem., 1995, 397, 139-147.

55 H. L. Lord, W. Zhan and J. Pawliszyn, Comprehensive Sampling and Sample Preparation, 2012, vol. 2, pp. 677-697.
56 S. H. Ng, J. Wang, D. Wexler, K. Konstantinov, Z. P. Guo and H. K. Liu, Angew. Chem., Int. Ed., 2006, 45, 6896-6899.

57 S. Werner, M. Haumann and P. Wasserscheid, Annu. Rev. Chem. Biomol. Eng., 2010, 203-230.

58 C. A. Schroll, S. Chatterjee, T. G. Levitskaia, W. R. Heineman and S. A. Bryan, Anal. Chem., 2013, 85, 9924-9931.

59 Y. Yoshida and G. Saito, J. Mater. Chem., 2006, 1254-1262.

60 D. R. McFarlane, J. Sun, J. Golding, P. Meakin and M. Forsyth, Electrochim. Acta, 2000, 45, 1271-1278.

61 M. Galiński, A. Lewandowski and I. Stepniak, Electrochim. Acta, 2006, 51, 5567-5580.

62 Y. Jiang, C. Guo and H. Liu, China Particuol., 2007, 5, 130-133.

63 R. E. Del Sesto, T. M. McCleskey, A. K. Burrell, G. A. Baker, J. D. Thompson, B. L. Scott, J. S. Wilkes and P. Williams, Chem. Commun., 2008, 447-449.

64 M. E. Danebrock, C. B. H. Evers and W. Jeitschko, J. Phys. Chem. Solids, 1996, 57, 381-387.

65 S. Hayashi and H. O. Hamaguchi, Chem. Lett., 2004, 33, 1590-1591.

66 Y. Yoshida and G. Saito, J. Mater. Chem., 2006, 16, 1254-1262.

67 I. De Pedro, D. P. Rojas, J. Albo, P. Luis, A. Irabien, J. A. Blanco and J. R. Fernández, J. Phys.: Condens. Matter, 2010, 22, 296006.

68 D. Kogelnig, A. Stojanovic, F. V.d. Kammer, P. Terzieff, M. Galanski, F. Jirsa, R. Krachler, T. Hofmann and B. K. Keppler, Inorg. Chem. Commun., 2010, 13, 1485-1488.

69 E. W. Krieger, B. M. Lee, H. Y. Emge, T. J. Wishart and J. F. Castner, Jr., Phys. Chem. Chem. Phys., 2010, 12, 8919-8925.

70 N. Deng, M. Li, L. Zhao, C. Lu, S. L. de Rooy and I. M. Warner, J. Hazard. Mater., 2011, 192, 1350-1357.

71 W. Zhu, P. Wu, L. Yang, Y. Chang, Y. Chao, H. Li, Y. Jiang, W. Jiang and S. Xun, Chem. Eng. J., 2013, 229, 250-256.

72 O. E. Zhuravlev, V. M. Nikol'Skii and L. I. Voronchikhina, Russ. J. Gen. Chem., 2014, 84, 1141-1145.

73 A. García-Saiz, P. Migowski, O. Vallcorba, J. Junquera, J. A. Blanco, J. A. González, M. T. Fernández-Díaz, J. Rius, J. Dupont, J. R. Fernández and I. D. Pedro, Chem. - Eur. J., 2014, 20, 72-76.

74 X. Li, Q. Zhou, X. Lu and S. Zhang, J. Mol. Liq., 2017, 243, 285-292.

75 J.-C. Chang, C.-H. Yang, I.-W. Sun, W.-Y. Ho and T.-Y. Wu, Materials, 2018, 11, 2539. 